\title{
ОБ ОСУЩЕСТВЛЕНИИ ПРЕБЫВАЮЩИМИ В ОТСТАВКЕ СУДЬЯМИ ОПЛАЧИВАЕМОЙ ДЕЯТЕЛЬНОСТИ
}

\author{
Л. Е. Кравцова \\ Амурский государственный университет \\ Поступила в редакцию 17 мая 2021 г.
}

\begin{abstract}
Аннотация: исследуется сущность и характер научной, педагогической и иной творческой деятельности, которую вправе осуществлять пребываюшие в отставке судьи. В иентр внилания ставится неполнота регулирования статуса судьи в отставке в сфбере труда. Расслатривается вопрос об определении пребывающил в отставке судьял правовых ориентиров для трудоустройства. Установлена необходилость расширения области применения судьяли в отставке профбессиональньх знаний.
\end{abstract}

Ключевые слова: статус судьи, судья в отставке, оплачиваемая деятельность.

\begin{abstract}
: the nature and nature of scientific, pedagogical and other creative activities that retired judges are entitled to carry out, are investigated. The research is based on the conclusions of the Commission of the Council of Judges of the Russian Federation on Ethics. Incomplete regulation of the status of a retired judge in the field of labor is put in the focus is in the problem. The main idea of the article is determination of legal guidelines for employment for retired judges. The conclusions is drawn on the need to expand the scope of application of professional knowledge by retired judges,
\end{abstract}

Key words: status of a judge, retired judge, paid activity.

После прекращения основной профессиональной деятельности ряд судей приобретают статус судьи в отставке, под которым понимается почетный уход или почетное удаление судьи с должности с сохранением за лицом, пребывающим в отставке, звания судьи, гарантий личной неприкосновенности и принадлежности к судейскому сообществу (Закон РФ «О статусе судей в Российской Федерации» от 26 июня 1992 г. № 33231-I, далее - Закон о статусе судей $\left.{ }^{1}\right)$. Уход с судейской должности не влечет

46 утрату присущих судьям качеств, таких как профессионализм, знание закона, большой объем долговременной памяти, развитое логическое и интуитивное мышление, объективность, умение управлять чужой эмоциональной сферой. Уходя в отставку в сравнительно молодом возрасте, такие судьи, как правило, в состоянии продолжать активную общественную и профессиональную жизнь. Но нередко пребывающие в отставке судьи не могут самостоятельно определить, будет или нет противоречить статусу судьи та деятельность, которой они хотели бы заняться после прекращения отправления правосудия. Так, за период с 2012 г. по 2016 г.

${ }^{1}$ О статусе судей в Российской Федерации : закон РФ от 26 июня 1992 г. № 3231-І (в ред. от 30.12.2020) // Ведомости СНД РФ и ВС РФ. 1992. № 30. Ст. 1792.

(С) Кравцова Л. Е., 2021 
были прекращены полномочия свыше 5500 судей, отставка 472 судей прекращена в большинстве случаев в связи с намерением заняться работой, не разрешенной законом для судей в отставке ${ }^{2}$. То есть около полутысячи судей из числа ушедших в отставку не нашли применения своим знаниям и опыту в рамках тех видов деятельности, которые совместимы со статусом судьи.

Одной из причин в неверном определении вида оплачиваемой деятельности, допустимой для пребывающего в отставке судьи, на наш взгляд, является отсутствие в Законе о статусе судей и Кодексе судейской этики четких и однозначных критериев, которые позволили бы судьям в отставке найти себе применение после ухода с судейской работы без опасения потерять соответствующие гарантии и материальное обеспечение.

Так, пребывающий в отставке судья Е., имея 11-летний судейский стаж и не достигнув возраста 55 лет, искал работу через отдел занятости населения, где был зарегистрирован в качестве безработного и получал пособие по безработице. Не будучи трудоустроен, он неоднократно представлял интересы граждан в судах различных инстанций на основании доверенностей и по ходатайствам сторон на возмездной основе, а когда в связи с несоблюдением им требований п. 3 ст. 3 Закона о статусе судей была прекращена его отставка, обратился в суд, поясняя, что, будучи в отставке, он не связан какими-либо ограничениями в выборе любой оплачиваемой работы, не состоял в трудовых отношениях и был вправе заниматься любой другой оплачиваемой деятельностью ${ }^{3}$.

Судья в отставке Г., не получающий пожизненного содержания, был признан безработным, два раза отказался от предложенной ему работы, оспаривал в судебном порядке приказ начальника органа занятости населения о приостановлении выплаты пособия по безработице, в дальнейшем обратился в КС РФ, оспаривая конституционность подп. 5 п. 3 ст. 3, п. 4 ст. 3 Закона о статусе судей, полагая, что приведенные нормы нарушают его право свободно распоряжаться своими способностями к труду, выбирать род деятельности и профессию4.

Право пребывающих в отставке судей на регистрацию в службе занятости в целях поиска работы, допускаемой законодательством о статусе судей, на признание быть безработным и получение пособия по безработице, также являлось предметом рассмотрения комиссии Совета судей РФ по этике (далее - Комиссия по этике), положительно ответившей на этот вопрос ${ }^{5}$.

${ }^{2}$ Отчетный доклад председателя Высшей квалификационной коллегии судей Российской Федерации Н. B. Тимошина на IX Всероссийском съезде судей. URL: http://www.ssrf.ru/siezd-sudiei/22908 (дата обращения: 20.04.2021).

${ }^{3}$ Определение ВС РФ от 15 марта 2007 г. № KAC07-38. URL: http://vsrf.ru/ stor_pdf.php?id=165522 (дата обращения: 21.04.2021).

${ }^{4}$ Определение КС РФ от 25 февраля 2010 г. № 293-O-O. URL: http://doc.ksrf.ru/ decision/KSRFDecision24295.pdf (дата обращения: 21.04.2021).

${ }^{5} \mathrm{O}$ праве судьи, пребывающего в отставке и не получающего ежемесячное денежное содержание, зарегистрироваться в органах службы занятости в целях поиска работы, разрешаемой законодательством о статусе судей, быть признанным безработным и получать пособие по безработице : заключение комиссии Совета судей Российской Федерации по этике от 15 января 2021 г. № 2-KЭ. URL: http:// www.ssrf.ru/dokumienty/zakliuchieniia/40332 (дата обращения: 24.04.2021). 
Обращение в Комиссию по этике по вопросу о соответствии статусу судьи регистрации в качестве безработного и получения пособия по безработице подтверждают наличие у пребывающих в отставке судей сомнений в вопросах поиска допустимой работы. Приведенные примеры, в которых судьи в отставке состояли на учете в центре занятости населения, были признаны безработными, являлись получателями пособия по безработице, свидетельствуют о существующих сложностях в трудоустройстве судей в отставке, особенно с так называемым «отложенным правом» на ежемесячное пожизненное содержание. Судья в отставке, получающий указанную выплату, имеет источник обеспечения своей жизнедеятельности, тогда как перед судьей в отставке с «отложенным» правом на его получение до достижения соответствующего возраста возникает проблема поиска средств для обеспечения себя и своей семьи. Существующее регулирование правового положения пребывающих в отставке судей, в частности занятия какой-либо оплачиваемой деятельностью судьями в отставке с отложенным правом на получение ежемесячного пожизненного содержания, создает угрозу утраты ими своего статуса и не способствует созданию баланса между гарантиями их материального обеспечения и вытекающими из их статуса ограничениями. Разъяснение норм, касающихся пребывающих в отставке судей, происходит узконаправленно, при возникновении конкретных жизненных ситуаций, что в целом не способствует укреплению судебной власти. Крайне негативные последствия, влекущие утрату материального и социального обеспечения для лиц, отправлявших правосудие, свидетельствуют о наличии неразрешенных вопросов в сфере допустимой для судей в отставке оплачиваемой деятельности. Об актуальности этих вопросов свидетельствует и постоянное увеличение численности бывших судей и судей, пребывающих в отставке (если число судей, получающих ежемесячное пожизненное содержание, в 2009 г. (без учета судей арбитражных судов) было $8330^{6}$, на 31 декабря - 2020 г. - уже $\left.19818^{8}\right)$.

Судья, как это предусмотрено Кодексом судейской этики, может заниматься различными видами внесудебной деятельности, включая научную, образовательную, творческую, общественную, благотворительную

48 и иные виды деятельности, и участвовать в различных публичных мероприятиях, если это не противоречит законодательству о статусе судей

${ }^{6}$ Отчет о деятельности Судебного департамента при Верховном Суде РФ в 2009 г. URL: http://www.cdep.ru/index.php?id=195\&item=483 (дата обращения: 30.04.2021).

${ }^{7}$ Отчет об итогах деятельности Судебного департамента при Верховном Суде РФ за 2015 г. : решение коллегии СД при ВС РФ от 29 марта 2016 г. № 1/1-скд. URL: http://www.cdep.ru/userimages/OTChYoT_2015.pdf (дата обращения: 20.04.2021).

${ }^{8}$ Отчет об итогах деятельности Судебного департамента при Верховном Суде РФ за 2020 г. : решение коллегии СД при ВС РФ от 30 марта 2021 г. № 3/1-скд. URL: http://www.cdep.ru/userimages/Otchet_SD_za_2020_g.pdf (дата обращения: 20.04.2021). 
в РФ и не причиняет ущерб интересам правосудия ${ }^{9}$. Несмотря на то, что Советом судей РФ четко определены критерии для занятия перечисленными видами деятельности - отсутствие противоречия Закону о статусе судей и непричинение такой деятельностью ущерба интересам правосудия ${ }^{10}$, вопросы вызывает реальная возможность для пребывающих в отставке судьям осуществлять научную, педагогическую или творческую деятельность. Ограниченные возможности пребывающих в отставке судей по применению своих сил и способностей по окончании судейской карьеры во многом связаны с отсутствием четкого понимания существа допустимой оплачиваемой деятельности, в частности научной, педагогической, иной творческой.

Для определения характера научной деятельности следует обратиться к Федеральному закону от 23 августа 1996 г. № 127-ФЗ «О науке и государственной научно-технической политике», в силу которого научная (научно-исследовательская) деятельность - это деятельность, направленная на получение и применение новых знаний, виды научной деятельности - это фрундаментальные научные исследования, прикладные научные исследования, поисковые научные исследования. Научным работником (исследователем) является гражданин, обладающий необходимой квалификацией и профессионально занимающийся научной и (или) научно-технической деятельностью ${ }^{11}$.

Предоставление судьям права на ведение научно-педагогической деятельности, как справедливо замечают правоведы, позволяет привлечь в образовательные учреждения наиболее подготовленных юристов, существенно повысить качество обучения студентов. По этой причине во многих ведущих вузах страны работает значительное число судей, в том числе имеющих ученые степени и ученые звания. Примерами тому являются работа судей Верховного Суда РФ, Конституционного Суда РФ, Московского городского и Московского областного судов и судей в отставке в Российском государственном университете правосудия (г. Москва), в Институте государства и права PAH (г. Москва). Нельзя также не согласиться с выводом о том, что сочетание в преподавании знаний и опыта ученых и практиков обеспечивает высокий уровень обучения и более полное соответствие целям получения профессионального образования ${ }^{12}$.

${ }^{9}$ Кодекс судейской этики от 19 декабря 2012 г. : утвержден VIII Всероссийским съездом судей 19 декабря 2012 г. URL: https:/www.garant.ru/products/ipo/ prime/doc/70201432/ (дата обращения: 23.04.2021).

${ }^{10}$ Кодекс судейской этики : сб. заключений комиссии Совета судей Российской Федерации по этике (2009-2016) от 18.10.2019. URL: http://www.ssrf.ru/ dokumienty/zakliuchieniia/34890 (дата обращения: 23.04.2021).

${ }^{11} \mathrm{O}$ науке и государственной научно-технической политике : федер. закон от 23 августа 1996 г. № 127-ФЗ (в ред. от 08.12.2020) // Собр. законодательства Рос. Федерации. 1996. № 35. Ст. 4137.

${ }^{12}$ См.: Качлазов О. Х., Цалиев А. М. Правовые ограничения осуществления судьей преподавательской деятельности // Российская юстиция. 2009. № 8. С. 7. 
Фактически, на наш взгляд, реальная возможность научной деятельности имеется у очень небольшой части пребывающих в отставке судей. Осуществлять научную деятельность труднее всего судьям, которые ушли в отставку из небольших городских и районных судов, расположенных в населенных пунктах, где нет профильных вузов или вообще нет высших учебных заведений. Поэтому представляется, что научная деятельность как сложная интеллектуальная творческая работа, имеющая целью не только получение, но и использование новых знаний в последующем, не может быть широко распространена среди судей в отставке. Для того чтобы стать субъектом научной деятельности, необходима специальная подготовка, которой, как правило, ко времени выхода в отставку обладают те из судей, кто уже имеет ученую степень. Но для ее получения требуются огромные умственные усилия и временные затраты. В условиях существующей служебной нагрузки у большей части судей страны выполнение ими научных исследований в период исполнения обязанности по отправлению правосудия труднодостижимо. Представляется, что научной деятельностью в отставке в большинстве случаев могут заняться судьи, имеющие ученую степень (т. е. работавшие до назначения судьей преподавателями либо получившие ученую степень в ходе исполнения судейских обязанностей), либо судьи, которые, будучи в отставке, только пожелают начать заниматься научными исследованиями. Для занятия научной деятельностью на профессиональном уровне может потребоваться получение соответствующей ступени высшего образования - аспирантуры, продолжительность обучения в которой составляет 3-4 года. Учитывая возраст уходящих в отставку судей, имеющих, как правило, более двадцати лет трудового стажа, поступление в аспирантуру и последующая защита научной работы не всегда для них прили целесообразна.

Законом о статусе судей предусмотрено право судьи, в том числе судьи в отставке, осуществлять педагогическую деятельность ${ }^{13}$. Кодекс судейской этики говорит о праве судьи заниматься образовательной и преподавательской деятельностью (ст. 14 и 15$)^{14}$, однако содержание понятия этих видов деятельности ни законом, ни Кодексом не раскрывается. Названы лишь условия осуществления такой деятельности - она не должна препятствовать исполнению обязанностей судьи, не может служить уважительной причиной отсутствия на заседании без согласия председателя соответствующего суда, не может финансироваться (если иное не предусмотрено законодательством РФ, определенными договоренностями) исключительно за счет средств иностранных государств,

${ }^{13}$ О статусе судей в Российской Федерации : закон РФ от 26 июня 1992 г. № 3231-І (в ред. от 30.12.2020) // Ведомости СНД РФ и ВС РФ. 1992. № 30. Ст. 1792.

${ }^{14}$ Кодекс судейской этики от 19 декабря 2012 г. : утвержден VIII Всероссийским съездом судей 19 декабря 2012 г. URL: https:/www.garant.ru/products/ipo/ prime/doc/70201432/ (дата обращения: 23.04.2021). 
международных и иностранных организаций, иностранных граждан и лиц без гражданства.

Известно обращение судьи в отставке в Комиссию по этике о возможности работать воспитателем семейной группы при муниципальном бюджетном образовательном учреждении. Ссылаясь на Закон РФ от 29 декабря 2012 г. № 273-ФЗ «Об образовании в Российской Федерации» (далее - Закон об образовании), Комиссия пришла к выводу, что воспитатель дошкольного образовательного учреждения является педагогическим работником, и как педагогическая деятельность работа пребывающего в отставке судьи в такой должности не противоречит законодательству о статусе судей (вне зависимости от возраста судьи в отставке и его стажа работы в должности судьи). Но как трудовая деятельность, которая сводится исключительно к присмотру и уходу за детьми, она не предусматривает участия в образовательной деятельности и педагогической не является ${ }^{15}$. То есть работа судьей в отставке воспитателем семейной группы и осуществление присмотра за детьми может привести к нарушению законодательства о статусе судей, так как эта деятельность не будет педагогической, но при этом неясно, какой ущерб в этом случае может быть причинен интересам правосудия.

Образование - это единый целенаправленный процесс воспитания и обучения, а воспитание - это деятельность, направленная на развитие личности; обучение представляет собой целенаправленный процесс организации деятельности обучающихся по овладению знаниями, умениями, навыками и компетенцией. Педагогическим работником является фоиическое лицо, которое состоит в трудовых, служебных отношениях с организацией, осуществляющей образовательную деятельность, и выполняет обязанности по обучению, воспитанию обучающихся и (или) организации образовательной деятельности. Правом на занятие педагогической деятельностью согласно ст. 46 Закона об образовании обладают лица, имеющие среднее профессиональное или высшее образование и отвечающие квалифрикационным требованиям и (или) профессиональным стандартам $^{16}$. Конституционный Суд РФ в постановлении от 14 ноября 2018 г. № 41-П отметил, что эта норма направлена на исключение замещения должностей педагогов, воспитателей в образовательных организациях лицами, не имеющими профессиональной подготовки соответствующего уровня $^{17}$. Профрессиональным стандартом «Педагог (педагогическая де-

${ }^{15} \mathrm{O}$ возможности судьи, пребывающего в отставке, работать воспитателем семейной группы при муниципальном бюджетном дошкольном образовательном учреждении : заключение Комиссии Совета судей Российской Федерации по этике от 31 мая 2017 г. № 2-кэ. URL: http://www.ssrf.ru/dokumienty/zakliuchieniia/24975 (дата обращения: 03.02.2020).

${ }^{16}$ Об образовании в Российской Федерации : федер. закон от 29 декабря 2012 г. № 273-ФЗ (в ред. от 24.03.2021) // Собр. законодательства Рос. Федерации. 2012. № 53 (ч. 1). Ст. 7598.

${ }^{17} \mathrm{O}$ проверке конституционности статьи 46 Федерального закона «Об образовании в Российской Федерации» в связи с жалобой гражданки И. В. Серегиной : 


\section{Вестник ВГУ. Серия: Право}

ятельность в сфрере дошкольного, начального общего, основного общего, среднего общего образования) (воспитатель, учитель)» к учителю и воспитателю предъявляются требования о наличии высшего или среднего профессионального образования в рамках укрупненных групп направлений подготовки высшего образования и специальностей среднего профрессионального образования «Образование и педагогические науки» или в области, соответствующей преподаваемому предмету, либо высшее образование или среднее профессиональное образование и дополнительное профрессиональное образование по направлению деятельности в образовательной организации ${ }^{18}$.

Приведенные условия допуска к занятию педагогической деятельностью предполагают для судей в отставке, вероятнее всего, необходимость получения дополнительной профессиональной подготовки. Это требует финансовых и временных затрат и препятствует осуществлению педагогической деятельности непосредственно после ухода судьи в отставку, особенно в случаях «отложенного» права на получение ежемесячного пожизненного содержания при отсутствии у пребывающего в отставке судьи иного дохода. Кроме того, как следует из проведенного «Право.ру» опроса, преподавательская работа часто малооплачиваемая, особенно для тех, кто не состоит в штате образовательной организации, найти такую работу непросто; рынок научной и преподавательской деятельности ограничен, особенно в отдаленных от столицы регионах, и в преподавателях без научной степени вуз не заинтересован ${ }^{19}$.

Кроме того, лицо, осуществляющее педагогическую деятельность, подпадает под действие Закона об образовании. Исключений в отношении каких-либо категорий работников, в том числе судей в отставке, приведенный закон не содержит. Статья 47 закона содержит понятие «правовой статус педагогического работника» - это совокупность прав и

일 свобод (в том числе академических прав и свобод), трудовых прав, социальных гарантий и компенсаций, ограничений, обязанностей и ответственности, которые установлены законодательством Российской Федерации и законодательством субъектов РФ ${ }^{20}$. Но пребывающий в отставке судья обладает своим, судейским, статусом - за ним в силу ст. 15 Закона 52 о статусе судей сохраняются звание судьи, членство в судейском сообеепостановление Конституционного Суда РФ от 14 ноября 2018 г. № 41-П. URL: http://doc.ksrf.ru/decision/KSRFDecision363389.pdf (дата обращения: 20.04.2021).

18 Об утверждении профрессионального стандарта «Педагог (педагогическая деятельность в сфере дошкольного, начального общего, основного общего, среднего общего образования) (воспитатель, учитель)» : приказ Министерства труда и социальной защиты РФ от 18 октября 2013 г. № 544н // Рос. газета. 2013. № 285.

19 Лучший выбор для судьи в отставке - преподавание, но «запрет на работу» надо смягчать - итоги опроса : Право.py. URL: https:/pravo.ru/review/ view/61492/ (дата обращения: 20.04.2021).

${ }^{20}$ Об образовании в Российской Федерации : федер. закон от 29 декабря 2012 г. № 273-ФЗ (в ред. от 24.03.2021) // Собр. законодательства Рос. Федерации. 2012. № 53 (ч. 1). Ст. 7598. 
стве, гарантии неприкосновенности. На таких судей не распространяются гарантии неприкосновенности и приостанавливается их членство в судейском сообществе только в случае работы в органах государственной власти, органах местного самоуправления, государственных и муниципальных учреждениях, в профсоюзных и иных общественных объединениях, в качестве помощника депутата Государственной Думы или члена Совета Федерации Федерального Собрания РФ, помощника депутата законодательного (представительного) органа субъекта РФ (п. 4 ст. 3 Закона о статусе судей $)^{21}$. По смыслу закона, указанные гарантии сохраняются при осуществлении судьей в отставке научной, педагогической и творческой деятельности. Означает ли это, что при осуществлении педагогической деятельности пребывающие в отставке судьи приобретают правовой статус педагогических работников? Если да, то надлежит решить вопрос о наличии (отсутствии) у таких судей права на меры социальной поддержки, предоставляемые педагогам как на фредеральном уровне, так и на уровне субъектов РФ. К ним относятся, в частности, право на предоставление вне очереди жилых помещений по договорам сощиального найма, из специализированного жилищного фонда; право педагогических работников сельской местности на компенсацию расходов по оплате жилых помещений, отопления, освещения ${ }^{22}$. Сумма указанной компенсации, например, выплачивается ежемесячно, одновременно с выплатой заработной платы, на основании трудового договора или трудовой книжки и документа, подтверждающего место жительства, ее размер фоиксирован ${ }^{23}$.

Вопрос о том, насколько использование пребывающим в отставке судьей при осуществлении им педагогической деятельности гарантий и компенсаций, принадлежащих последним, согласуется со статусом судьи, и не приведет ли получение таких гарантий к умалению авторитета судебной власти, на наш взгляд, можно решить с учетом позиции Комиссии по этике, сфрормулированной в заключении от 25 января 2018 г. № 5-КЭ. В нем рассмотрен вопрос о том, является ли осуществление судьей в отставке ухода за нетрудоспособным лицом и получение им причитающейся компенсационной выплаты «иной оплачиваемой деятельностью», за-

${ }^{21}$ О статусе судей в Российской Федерации : закон РФ от 26 июня 1992 г. № 3231-І (в ред. от 30.12.2020) // Ведомости СНД РФ и ВС РФ. 1992. № 30. Ст. 1792.

22 Об образовании в Российской Федерации : федер. закон от 29 декабря 2012 г. № 273-ФЗ (в ред. от 24.03.2021) // Собр. законодательства Рос. Федерации. 2012. № 53 (ч. 1). Ст. 7598.

${ }^{23} \mathrm{O}$ предоставлении компенсации расходов на оплату жилых помещений, отопления и освещения педагогическим работникам, руководителям, заместителям руководителей, руководителям структурных подразделений и их заместителям, состоящим в штате по основному месту работы в федеральных государственных образовательных организациях, проживающим и работающим по трудовому договору в сельских населенных пунктах, рабочих поселках (поселках городского типа) : постановление Правительства РФ от 26 октября 2013 г. № 963 // Собр. законодательства Рос. Федерации. 2013. № 44. Ст. 5761. 


\section{Вестник ВГУ. Серия: Право}

прет на осуществление которой установлен в ст. 3 Закона о статусе судей. Установив отсутствие запрета на осуществление судьей в отставке такой деятельности, назначение ему компенсационной выплаты по уходу Комиссия поставила в зависимость от того, получает ли судья в отставке ежемесячное пожизненное содержание. Комиссия пришла к выводу, что такую выплату вправе получать неработающий, трудоспособный, фрактически осуществляющий уход за нетрудоспособным лицом, пребывающий в отставке судья, которому не назначено ежемесячное пожизненное содержание $^{24}$. Этот подход можно применить и при решении вопроса о наличии или отсутствии у судей в отставке, осуществляющих педагогическую деятельность, права на льготы и компенсации для педагогов. В случае «отложенного» права на получение судьей в отставке ежемесячного пожизненного содержания, когда доход от преподавательской деятельности является его единственным источником существования, получение имущественных льгот, которыми пользуются педагоги, на наш взгляд, не может рассматриваться как нарушение судьей запретов и ограничений, установленных Законом о статусе судей. В случае, если судья в отставке является получателем ежемесячного пожизненного содержания, которое по своей природе относится к социальным выплатам из бюджета и по своему размеру значительно превышает размер причитающихся педагогическим работникам социальных льгот и компенсаций, использование таким судьей в отставке указанных гарантий педагогического работника навряд ли можно признать совместимым со статусом судьи. Несмотря на то что, например, постановление Правительства РФ о предоставлении компенсации расходов на оплату жилых помещений от 26 октября 2013 г. № 963 не содержит запрета на использование этой компенсации лицами, получающими иные социальные выплаты, пребывающий в отставке судья обязан определять соответствие своей деятельности публично-правовому статусу судьи и требованиям Кодекса судейской этики.

Кроме научной и педагогической, Закон о статусе судей и Кодекс судейской этики относит к иной разрешенной для судей в отставке оплачиваемой деятельности иную творческую деятельность. Содержание понятия творческой деятельности в приведенных нормативных актах не раскрыто, что вызвало ряд обращений в Комиссию по этике. бывающего в отставке судьи по вопросу осуществления деятельности в средствах массовой информации. Комиссия признала, что занятие деятельностью, связанной с реализацией фрункций по должностям служащих средств массовой информации относится к творческой деятельности, но не исключает обязанность судьи в отставке, работающего в штате ре-

${ }^{24} \mathrm{O}$ допустимости получения ежемесячной компенсационной выплаты судьей в отставке, осуществляющим уход за инвалидом I группы, а также за престарелым, нуждающимся по заключению лечебного учреждения в постоянном постороннем уходе либо достигшим возраста 80 лет : заключение Комиссии Совета судей РФ по этике от 25 января 2018 г. № 5-КЭ. URL: http://www.ssrf.ru/dokumienty/ zakliuchieniia/27002 (дата обращения: 20.04.2020). 
дакции СМИ, воздерживаться от публичных высказываний по вопросу, который является предметом рассмотрения в суде, до вступления в законную силу судебного акта по этому вопросу, а также не допускать действий, которые могут привести к конфликту интересов либо иным образом поставить под угрозу независимость и беспристрастность суда ${ }^{25}$.

В заключении от 3 декабря 2014 г. по вопросу о праве судьи, пребывающего в отставке, работать в профессиональном музыкальном коллективе Комиссия по этике пришла к выводу, что ряд профрессий, таких как артисты оркестра духового, эстрадного оркестра и ансамбля, оркестра народных инструментов, концертные исполнители (всех жанров), относятся к должностям творческих работников, поэтому судья, пребывающий в отставке, может осуществлять деятельность в профессиональном музыкальном коллективе (играть на баяне) на платной основе. При этом ему надлежит избегать каких-либо преимуществ при определении размера вознаграждения, вызванного его высоким статусом, и соблюдать требования Закона о статусе судей ${ }^{26}$, тогда как индивидуальные условия оплаты труда творческих работников, с учетом характера их деятельности, могут быть установлены только исходя из опыта профессиональной деятельности, высокого профессионального мастерства, яркой творческой индивидуальности, широкого признания зрителей и общественности ${ }^{27}$.

Кроме того, в приведенных заключениях для определения содержания творческой деятельности Комиссия обратилась к содержанию постановления Правительства РФ от 28 апреля 2007 г. № 252 «Об утверждении перечня профессий и должностей творческих работников средств массовой информации, организаций кинематографии, теле- и видеосъемочных коллективов, театров, театральных и концертных организаций, цирков и иных лиц, участвующих в создании и (или) исполнении (экспонировании) произведений, особенности трудовой деятельности которых установлены Трудовым кодексом Российской Федерации», согласно которому ряд профессий, таких как артисты оркестра духового, эстрадного оркестра и ансамбля, оркестра народных инструментов, концертные исполнители (всех жанров), относятся к должностям творческих работников. Комиссия признала возможным отнести к творческой деятельности занятие

${ }^{25} \mathrm{O}$ праве судьи, пребывающего в отставке, заниматься оплачиваемой деятельностью в штате редакции средства массовой информации : заключение Комиссии Совета судей РФ по этике от 25 мая 2011 г. № C/КЭ-5. URL: http:// www.ssrf.ru/dokumienty/zakliuchieniia/10363 (дата обращения: 20.04.2020).

${ }^{26} \mathrm{O}$ праве судьи, пребывающего в отставке, работать в профессиональном музыкальном коллективе : заключение Комиссии Совета судей РФ по этике от 3 декабря 2014 г. URL: http://www.ssrf.ru/dokumienty/zakliuchieniia/34890 (дата обращения: 24.04.2021).

27 Примерное положение об оплате труда работников фредеральных бюджетных учреждений культуры, искусства, образования и науки, находящихся в ведении Министерства культуры Российской Федерации : приказ Министерства культуры РФ от 26 августа 2016 г. № 1947 // Бюллетень нормативных актов федеральных органов исполнительной власти. 2016. № 42. 


\section{Вестник ВГУ. Серия: Право}

деятельностью, связанной с реализацией функций по названным должностям. Но приведенный перечень содержит 170 наименований должностей служащих и 19 наименований профессий рабочих различных организаций (СМИ, организаций кинематографии, теле- и видеосъемочных коллективов, театров, театральных и концертных организаций, цирков), а также иных лиц, которые участвуют в создании и (или) исполнении (экспонировании) произведений ${ }^{28}$. В перечень включены профрессии и должности лиц, как создающих культурные ценности, так и тех, кто непосредственно их не создает, но участвует в организации их представления и показа зрителю (экспонировать - буквально «выставить для обозрения» ${ }^{29}$ ). Например, механик по обслуживанию съемочной техники, механик по обслуживанию звуковой техники, осветитель и т. д. Вывод Комиссии по этике об отнесении к творческой только деятельности, связанной с реализацией функций по названным в заключении должностям (артисты оркестра духового, эстрадного оркестра и ансамбля, оркестра народных инструментов, концертные исполнители (всех жанров), оставляет открытым вопрос о возможности пребывающему в отставке судье выполнять работу по другим, перечисленным в перечне, должностям и профессиям. Самостоятельно отнеся оплачиваемую работу по одной из должности или профессии в приведенном списке к творческой деятельности, пребывающие в отставке судьи находятся в ситуации риска, когда выполняемая ими работа может быть признана не совместимой со статусом судьи.

Еще одно заключение Комиссии по этике касается права судьи, пребывающего в отставке, работать на платной основе экскурсоводом ${ }^{30}$. Запрос затрагивал два аспекта - статус учреждения, в котором работает экскурсовод, и характер деятельности по соответствию статусу судьи. При обсуждении вопроса о характере работы экскурсовода Комиссия по этике пришла к выводу, что она не относится к творческой деятельности. С такой позицией органа судейского сообщества не согласился А. С. Вражнов, отметивший, что недостаточно вывода Комиссии только на основе анализа содержания квалификационных характеристик должностей работников организаций сферы туризма и одноименного профессионального стандарта без соотнесения с практической деятельностью экскурсовода (гида). А. С. Вражнов отметил, что экскурсоводу (гиду) для выполнения

28 Перечень профессий и должностей творческих работников средств массовой информации, организаций кинематографии, теле- и видеосъемочных коллективов, театров, театральных и концертных организаций, цирков и иных лиц, участвующих в создании и (или) исполнении (экспонировании) произведений, особенности трудовой деятельности которых установлены Трудовым кодексом Российской Федерации : постановление Правительства РФ от 28 апреля 2007 г. № 252 // Собр. законодательства Рос. Федерации. 2007. № 19. Ст. 2356.

${ }^{29}$ Ожегов С. И. Словарь русского языка. М., 2005. С. 885.

${ }^{30} \mathrm{O}$ праве судьи, пребывающего в отставке, работать на платной основе экскурсоводом : заключение Комиссии Совета судей РФ по этике от 25 января 2018 г. № 2-КЭ. URL: http://www.ssrf.ru/dokumienty/zakliuchieniia/26999 (дата обращения: 21.04.2021). 
своих профессиональных обязанностей требуется не только умение излагать заранее подготовленный материал, но и перерабатывать его с учетом возрастного, образовательного уровня слушателей, менталитета туристов определенной национальности, высказывать собственное мнение об объектах культурного наследия и пр. ${ }^{31}$

Автору эта позиция представляется верной, поскольку, определяя характер творческой работы, следовало бы исходить из существа этого вида деятельности. Творчество - это создание новых по замыслу культурных, материальных ценностей, а творческий означает «созидающий, самостоятельно создающий что-то новое, оригинальное» ${ }^{32}$. Согласно Основам законодательства РФ о культуре, творческая деятельность - это создание культурных ценностей и их интерпретация; к культурным ценностям относятся нравственные и эстетические идеалы, нормы и образцы поведения, языки, диалекты и говоры, национальные традиции и обычаи, исторические топонимы, фольклор, художественные промыслы и ремесла, произведения культуры и искусства, результаты и методы научных исследований культурной деятельности, имеющие историко-культурную значимость здания, сооружения, предметы и технологии, уникальные в историко-культурном отношении территории и объекты ${ }^{33}$. Экскурсовод как руководитель экскурсии собирает и изучает исторические материалы и документы, материалы архивов, статистические данные, иные документы и материалы, содержащие сведения об объектах экскурсий; готовит индивидуальные тексты экскурсий, публичных выступлений; участвует в разработке новых тем, читает экскурсионные лекции по культуре и истории и т. д. ${ }^{34}$ Поскольку экскурсовод (гид) - это профрессионально подготовленное лицо, осуществляющее деятельность по ознакомлению экскурсантов (туристов) с объектами показа в стране (месте) временного пребывания ${ }^{35}$, его деятельность, связанную с изучением культурных ценностей и их истолкованием (или интерпретацией) с целью передачи сведений о них туристам, по смыслу Основ законодательства о культуре, можно расценить как творческую.

${ }^{31}$ См.: Вражнов А. С. К вопросу об иной творческой деятельности судьи // Российский судья. 2018. № 12. С. 41.

32 Ожегов С. И. Словарь русского языка / под общ. ред. Л. И. Скворцова. М., 2005. C. 775.

${ }^{33}$ Основы законодательства Российской Федерации о культуре : закон РФ от 9 октября 1992 г. № 3612-I (в ред. от 01.03.2020) // Ведомости СНД РФ и ВС РФ. 1992. № 46. Ст. 2615.

34 Единый квалификационный справочник должностей руководителей, специалистов и служащих, раздел «Квалификационные характеристики должностей работников организаций сферы туризма» : приказ Министерства здравоохранения и социального развития РФ от 12 марта 2012 г. № 220н // Бюллетень нормативных актов федеральных органов исполнительной власти. 2012. № 29.

${ }^{35}$ Об основах туристской деятельности в Российской Федерации : федер. закон от 24 ноября 1996 г. № 132-ФЗ (в ред. от 09.03.2021) // Собр. законодательства Рос. Федерации. 1996. № 49. Ст. 5491. 
Но не только труд работника музыкального коллектива и экскурсовода можно оценивать с точки зрения наличия в нем творческой компоненты. Например, ювелир занимается изготовлением и ремонтом высокохудожественных образцов ювелирных изделий для индивидуального, мелкого и среднесерийного производства, он должен знать виды художественной обработки драгоценных и цветных металлов и драгоценных камней, основные стилевые особенности декоративно-прикладного искусства ${ }^{36}$. Ученые высказывают мнение, что любая профессиональная деятельность, для выполнения которой требуются специальные познания, по своей природе является творческой (даже работа токаря или электрика, создающего систему «Умный дом», или столяра-краснодеревщика) ${ }^{37}$. Эта точка зрения не бесспорна, но вызвана, на наш взгляд, отсутствием четких критериев вида и характера деятельности, которую вправе осуществлять пребывающие в отставке судьи. Определяющее значение для возможности осуществления такой деятельности имеет вероятный конфоликт интересов как противоречие между личной заинтересованностью судьи и законными правами и интересами граждан, организаций, общества, могущее привести к причинению им вреда, к умалению судебной власти и высокого статуса судьи. Выявить такое противоречие из-за отсутствия в действующих правовых актах четкого определения научной, педагогической, творческой деятельности пребывающему в отставке судье непросто. Отсутствие надлежащего закрепления особенностей правового статуса судьи в отставке в сфере труда требует устранения пробелов в этой части и восполнения законодательства о статусе пребывающих в отставке судей рядом положений, в том числе об определении сущности педагогической и творческой деятельности. Правовой статус пребывающего в отставке судьи должен обеспечивать независимость судебной ждет их по окончании судейской карьеры, ограничивающем в значительной мере реализацию им своих прав как человека и гражданина, с тем чтобы российских судей после отставки ожидало не «тяжелое наследство статуса», а его сила.

\section{Библиографический список}

Вражнов А. С. К вопросу об иной творческой деятельности судьи // Российский судья. 2018. № 12 . С. 40-42.

Качлазов О. Х., Цалиев А. М. Правовые ограничения осуществления судьей преподавательской деятельности // Российская юстиция. 2009. № 8. C. $6-9$.

Ожегов С. И. Словарь русского языка. М., 2005. 896 с.

${ }^{36}$ Порядок применения Единого квалификационного справочника должностей руководителей, специалистов и служащих : постановление Минтруда РФ от 9 февраля 2004 г. № 9 // Бюллетень нормативных актов фредеральных органов исполнительной власти. 2004. № 14.

${ }^{37}$ См.: Вражнов А. С. К вопросу об иной творческой деятельности судьи // Российский судья. 2018. № 12. С. 42. 


\section{References}

Vrazhnov A. S. On the question of other creative activity of the judge // Russian judge. 2018. № 12. P. 40-42.

Kachmazov O. Kh., Tsaliev A. M. Legal restrictions on the judge's teaching activities // Russian Justice. 2009. № 8. P. 6-9.

Ozhegov S. I. Dictionary of the Russian language. M., 2005. 896 p.

\section{Для иитирования:}

Кравиова Л. Е. Об осуществлении пребывающими в отставке судьями оплачиваемой деятельности // Вестник Воронежского государственного университета. Серия: Право. 2021. № 3 (46). C. 46-59. DOI: https://doi.org/10.17308/vsu.proc.law.2021.3/3539

\section{Recommended citation:}

Kravtsova L. E. On implementation of paid activities by retired judges // Proceedings of Voronezh State University. Series: Law. 2021. № 3 (46). P. 46-59. DOI: https://doi. org/10.17308/vsu.proc.law.2021.3/3539

Алурский государственньй универсиmem

Кравиова Л. Е., аспирант

E-mail: larisafakeeva@yandex.ru
Amur State University

Kravtsova L. E., Post-graduate Student

E-mail: larisafakeeva@yandex.ru 